\title{
Ekmeklik buğday (Triticum aestivum) genotiplerinin gluten kalitesinin glutopik cihazı ile değerlendirilmesi
}

\author{
Evaluation of gluten quality of bread wheat (Triticum aestivum) genotypes with \\ glutopeak device
}

\begin{abstract}
Mehmet ŞAHIN ${ }^{* 1} \mathbb{D}$, Aysun GÖÇMEN AKÇACIK ${ }^{1} \mathbb{D}$, Seydi AYDOĞAN ${ }^{1}$ (D) Berat DEMiR $^{1}(\mathbb{D})$

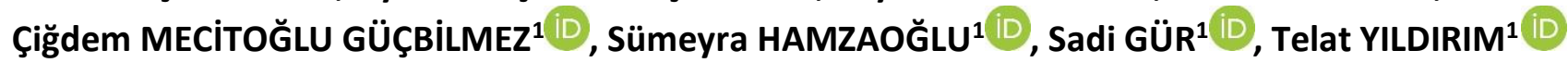

${ }^{1}$ Bahri Dağdaş Uluslararası Tarımsal Araştırma Enstitüsü Müdürlüğü-KONYA

To cite this article:

Şahin, M., Göçmen Akçacık, A., Aydoğan, S., Demir, B., Mecitoğlu Güçbilmez, Ç., Hamzaoğlu, S., Gür, S., \& Yıldırım, T. (2020). Ekmeklik buğday (Triticum aestivum) genotiplerinin gluten kalitesinin glutopik cihazı ile değerlendirilmesi. Harran Tarım ve Gıda Bilimleri Dergisi, 24(2):151164.

DOI: 10.29050/harranziraat.657208

Address for Correspondence: Mehmet ŞAHIN

e-mail:

mehmetsahin222@yahoo.com

Received Date:

09.12.2019

Accepted Date:

15.05.2020

(C) Copyright 2018 by Harran University Faculty of Agriculture. Available on-line at www.dergipark.gov.tr/harranziraat

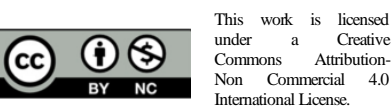

\section{öz}

Bu çalışma, 2017-2018 ve 2018-2019 yetiştirme sezonunda Bahri Dağdaş Uluslararası Tarımsal Araştırma Enstitüsü merkez lokasyonunda kuru ve sulu şartlarda 13 adet ekmeklik buğday genotipi ile yürütülmüştür. Deneme örnekleri öğütülmüş ve glutopik cihazında Hızlı Un Kontrol metoduna göre (Rapid Flour Check Method) analiz edilmiştir. Glutopik verileri maksimum torktan 15 saniye (s) önceki tork (AM), maksimum tork değeri (BEM), maksimum torka kadar geçen süre (PMT), maksimum torktan 15 saniye sonraki tork (PM), protein oranı (GPRT), yaş gluten (GGLT), enerji değeri (GW), su absorbsiyonu (GSAB), startup enerji (S. enerji) ve agregasyon enerji (Ag. enerji) olarak belirlenmiştir. Buğday kırmasında protein oranı (PRT) ve sertlik analizi (SRT), un örneklerinde Farinograf su absorbsiyonu (FSAB), Alveograf enerji değeri (AW), yaş gluten (YGLT) analizleri yapılmıştır. Glutopik cihazı verileri ile klasik yöntemle yapılan analizler değerlendirilip korelasyonlar incelenmiştir. AM ile FSAB $r=0.5579$ ve AW $r=0.3580$, BEM değeri ile FSAB $r=0.7665$, SRT $r=0.4089$, YGLT $r=0.3745$, PMT ile PRT arasında $r=-0.3583$, FSAB arasında $r=-0.6385 P<0.01$ düzeyinde önemli korelasyonlar bulunmuştur. GPRT ile PRT arasında $r=0.3592$, GGLT ile YGLT arasında $r=$ 0.3506, GW ile AW arasında $r=0.3919$, GSAB ile FSAB arasında $r=0.8280 P<0.01$ düzeyinde önemli ilişki olduğu belirlenmiştir. Glutopik cihazında elde edilen özellikler ile FSAB arasında yüksek korelasyon belirlenirken PRT, YGLT, AW arasında da önemli korelasyon olduğu tespit edilmiştir. PMT değeri ile diğer özellikler arasında negatif ilişki olduğu belirlenmiştir. Bu veriler doğrultusunda ekmeklik buğday genotiplerinin gluten kalitesinin değerlendirilmesinde, az örnekle kısa sürede analiz gerçekleştirildiğinden Glutopik cihazı kullanımının kolaylık sağlayacağını söyleyebiliriz.

Anahtar Kelimeler: Glutopik, Buğday, Alveograf enerji, Su absorbsiyonu, Protein

\section{ABSTRACT}

This study was carried out with 13 wheat genotypes in rainfed and irrigated conditions at the central land of Bahri Dağdaş International Agricultural Research Institute in 2017-2018 and 2018-2019 growing season. Test samples were milled by separating the bran and analyzed by Rapid Flour Check method at GlutoPeak device. GlutoPeak data; torque, 15 seconds ( $s$ ) before maximum torque (AM), maximum torque (BEM), time to maximum torque (PMT), 15 seconds after maximum torque (PM), protein content (GPRT), wet gluten (GGLT), energy value (GW), water absorption (GSAB), startup energy (S. energy) and aggregation energy (Ag. energy) values were determined. Protein ratio (PRT) and hardness analysis (SRT) in whole wheat, Farinograph water absorption (FSAB), Alveograph energy value (AW), wet gluten (YGLT) analyzes in flour samples were made. GlutoPeak device data and classical analyses were evaluated through correlations. Significant coefficient of correlations $(P<0.01)$ were found between AM and FSAB $(r=0.5579)$ and AW $(r=0.3580)$, 
BEM value with FSAB ( $r=0.7665)$, SRT $(r=0.4089)$, YGLT $(r=0.3745)$, PMT value with and PRT $(r=-0.3583)$ and FSAB $(r=-$ 0.6385). Significant relationships were determined between GPRT and PRT $r=0.3592$, between GGLT and YGLT $r=0.3506$, between $G W$ and $A W r=0.3919$, between GSAB and FSAB $r=0.8280$, at level $P<0.01$. While a high correlation was detected between the scores of GlutoPeak device and those of FSAB, significant correlation between PRT, YGLT and AW was also determined. There was a negative correlation between PMT and other properties. In the light of these data, we can say that the use of GlutoPeak equipment will provide convenience in the evaluation of gluten quality of bread wheat genotypes since analysis is performed in a short time with few samples.

Key Words: GlutoPeak, Wheat, Alveograph energy, Water absorption, Protein

\section{Giriş}

Dünya'da ekmeklik buğdaylar ekmek, bisküvi, kek, kraker, erişte makarna gibi hamur işlerinde yaygın bir şekilde kullanılmaktadır. Unun fonksiyonelliği ve çok yönlü olması gliadin ve glutenin depo proteinlerinin gluten oluşturma kapasitesi ile ilgilidir. Her buğday depo proteinlerine sahip olmasına rağmen, glutenin viskoelastik ağ oluşturması genotip ve çevre şartlarına göre farklılık göstermektedir (Gupta ve ark., 1992; Marti ve ark., 2015). Bu nedenle ekmeklik buğday ıslah programlarında gluten kalitesinin belirlenmesi büyük önem arz etmektedir. Günümüzde gelişen teknolojiye bağlı olarak gluten kalitesinin belirlenmesi için yeni teknikler ve metotlar geliştirmek için değişik çalışmalar yapılmaktadır. Gluten kalitesi belirlenmesi için miksograf, alveograf, farinograf, ekstensograf gibi cihazlarla su absorbsiyonu, enerji değeri, yoğrulmaya karşı tolerans değerleri ile gluten kalitesi hakkında bilgi edinilmektedir. Bu yöntemler fazla miktarda örnek gerektiren ve uzun zaman alan yöntemlerdir (Chandi ve Seetharaman 2012; Karaduman 2015; Güçbilmez ve ark., 2019). Reolojik analizler çok değişkenli bir yapıya sahip olmalarına rağmen, tahıl ve tahıl ürünlerinde az sayıda çalışma verileri kemometrik bir yaklaşımla ele alınmaktadır (Banu ve Aprodu, 2015; Pastor ve ark., 2016). Son zamanlarda bir çok gıda araştırmalarında verilerin değerlendirilmesinde giderek artan oranlarda kemometrik yöntemler (temel bileşenler analizi, kısmi korelasyon vb.) uygulanmaktadır (Giovenzana ve ark., 2013). Geleneksel olarak buğdayın reolojik özelliklerine ait veriler ile Glutopik endeksleri arasındaki korelasyon, Temel Bileşenler analizi (Principal Component Analysis,
PCA), kısmi korelasyon, biplot gibi bilgisayar yazılımları ile yapılabilmekte ve reolojik özelliklerin çok değişkenli doğası hakkında değerlendirme yapmaya imkan tanımaktadır (Malegori ve ark., 2018).

Ekmeklik buğday ıslah çalışmalarında geliştirilecek yeni çeşitlerin gluten kalitelerinin son kullanılacak ürün için uygun olması gerekmektedir. Islah çalışmalarının her kademesinde kalite kontrolü yapılarak gluten kalitesinin belirlenmesi yapılmaktadır. Özellikle kışlık dilim buğday ıslah çalışmalarının yapıldığı bölgelerde hasatla ekim arasındaki sürenin kısalığı nedeniyle gluten kalitesinin hızlı bir şekilde belirlenmesine ihtiyaç duyulmaktadır. Gözlem bahçesi, verim denemesi gibi ıslah kademelerinde gluten kalitesini ölçmek için numune miktarı az olabilmektedir. Son yıllarda gluten kalitesini ölçmek için daha az numune ile daha kısa sürede sonuç veren Glutopik cihazının kullanıldığı belirtilmektedir (Karaduman ve ark., 2015, Marti ve ark., 2015; Güçbilmez ve ark., 2019).

Glutopik cihazı karıştırma ünitesine $9 \mathrm{~g}$ un ve 9 $\mathrm{ml}$ su konularak, uygulanan metoda göre 19002750 devir/dakikada karıştırılmaktadır. Karıştırılma esnasında oluşan gluten ağı ve bu ağın parçalanması ile çizilen Glutopik diyagramının cihazın yazılımında hesaplanması ile elde edilen verilerin değerlendirilmesi gluten kalitesi hakkında bir bilgi vermektedir. Glutopik cihazı ile tam buğday unu ve rafine un için metot geliştirilmiş olup, her iki metot da gluten kalitesi hakkında fikir vermektedir. Glutopik diyagramında maksimum yüksekliğe ulaşmak için geçen zaman, maksimum yüksekliğe ulaşmadan $15 \mathrm{~s}$ öncesi tork değeri, maksimum yükseklikten $15 \mathrm{~s}$ sonraki tork değeri, diyagram alt kısmının alanı olarak agregasyon enerjisi hesap edilmekte ve gluten 
kalitesi hakkında temel bilgiler sağlamaktadır. Bu çalışmada ileri kademeye çıkmış, tescil edilmek için sunulmuş olan ekmeklik buğday genotiplerinin farklı lokasyonlarda yetiştirilmesi durumundaki gluten kalitelerinin Glutopik cihazı ile değerlendirilmesi amaçlanmıştır.

\section{Materyal ve Yöntem}

$\mathrm{Bu}$ çalışmada materyal olarak tescil edilmiş (Bezostaya, Bozkır, Taner, Şehzade) çeşitleri ile ileri çıkmış ve tescil edilmek için sunulmuş (Bayındır, Buhara, Hara, İkonya, Kilistra, Meke, Selçuklu, Tuğra, Yavuz) genotipleri kullanılmıştır. Genotipler 2017-2018 ve 2018-2019 yetiştirme sezonunda Bahri Dağdaş Uluslararası Tarımsal Araştırma Enstitüsü merkez lokasyonunda, kuru ve sulu şartlarda, ekilmiştir. Kuru şartlarda yağmura dayalı koşullarda yetiştirilmişken, sulu şartlarda yağmura ilaveten 3 defa (her sulamada yaklaşık $60 \mathrm{~mm}$ su verilmiştir) pivot sulama sistemi ile sulanarak yetiştirilmiştir. 2017-2018 yetiştirme döneminde $336 \mathrm{~mm}$, 2018-2019 döneminde ise $301.6 \mathrm{~mm}$ toplam yağış ölçülmüştür. Denemedeki iki tekerrüre ait materyal temizlendikten sonra laboratuvarda analize alınmıştır. 50 gram civarında buğday örneği Perten 3100 model (Perten instrument AB. Sweden) değirmende öğütülerek, $0.8 \mathrm{~mm}$ elek çapında kırma yapılmıştır. Kırmada, Leco FP 528 marka (Leco Inc, St Joseph, MI) cihazda Dumas yöntemi ile tespit edilen azot miktarı 5.7 faktörü ile çarpılarak protein analizi yapılmıştır (AOAC 992.23) (Anonim, 2000a). SKCS (Single Kernel Characterization System)'e göre kalibre edilmiş NIR (Foss DS2500 F) cihazında sertlik analizi yapılmıştır (AACC 55-31) (Anonim, 2000b). Un eldesi için, temizlenen buğday örneklerinden $1 \mathrm{~kg}$ alınarak, \%14.5 (v/w) nem esasına göre tavlanıp 12 saat bekledikten sonra Yücebaş YM1 marka (Yücebaş Machinery Analytical Equipment İzmir, Türkiye) un değirmeninde öğütülmüştür (AACC 26-95, AACC 26-50) (Anonim, 2000b).

Buğday ununda yaş gluten analizi Bastak marka gluten yıkama cihazı ile yapıımıştır (AACC 38-12A) (Anonim, 2000b). Farinograf su absorbsiyon kapasitesi (FSAB) AACC metot 54-21'e göre (Anonim, 2000b), Brabender Farinograph AT 50 (810151.001 model, Brabender, Duisburg, Germany) model cihazla belirlenmiş olup, Alveograf enerji değeri (AW) ise Chopin Alveo PC (Chopin, France) cihazı ile AACC metod 54-30'a göre (Anonim, 2000b) belirlenmiştir.

Glutopik testi Brabender marka (803400 model, Brabender GmbH\&Co KG, Duisburg, Germany) cihazla yapılmıştır. Glutopik cihazı ile ilgili tam buğday unu (buğday kırması) ve kepeksiz buğday ununu değerlendiren ayrı metotlar belirtilmiştir. Bu çalışmada, $9 \mathrm{~g}$ un örneği $9 \mathrm{~g}$ saf su ile $36{ }^{\circ} \mathrm{C}^{\prime}$ de 2750 devir/dakika hızla karıştırılmış, Wiertz (2018) tarafından belirtilen ve kepeksiz buğday unu ile Hızlı Un Kontrol metodu (Rapid Flour Check method) kullanılarak deneme materyali değerlendirilmiştir. Bu cihazda yapılan ölçümler cihazın yazılım programı (Glutopeak ${ }^{R}$ version 2.2.0) tarafından kaydedilmekte ve veriler hesaplanmaktadır. Bu veriler; maksimum torktan 15 s önceki tork (AM) birim olarak Glutopik Unit (GPU), glutenin toparlanma sürecindeki maksimum tork GPU (BEM), maksimum torktan 15 s sonraki tork GPU (PM), maksimum torka kadar geçen süre s (PMT), protein oranı $\%(w / w)$ (GPRT), yaş gluten $\%(w / w)$ (GGLT), W enerji değeri *10-4 J (GW), su absorbsiyon oranı \%(v/w) (GSAB), startup enerji değeri (S.enerji), agregasyon enerji değeri (Ag. enerji) olarak hesaplanmaktadır. Bu çalışmada 13 adet kışlık ekmeklik buğday genotipi 2017-2018 ve 20182019 yıllarında Konya merkez lokasyonunda kuru ve sulu koşullarda yetiştirilerek Glutopik cihazı ile kalite değerlendirmeleri yapılmış ve bu cihazın verdiği protein, Alveograf enerji (W), Farinograf su absorbsiyonu (FSAB) ve yaş gluten değerleri klasik usulde yapılan analiz sonuçları eşli t testi ile kıyaslanmıştır. Varyansların homojenliği kontrol edildikten sonra, homojen olan kuru ve sulu lokasyon denemeleri ayrı olarak Jump 11 (2014) programında istatistiki analiz (SAS Institute, ISBN:978-1-62959-560-3), kuru ve sulu lokasyon verileri birleştirilerek korelasyon ve temel bileşenler analizi (PCA) yapılmıştır. 


\section{Bulgular ve Tartışma}

2017-2018 ve 2018-2019 yılı kuru ve sulu lokasyonda yetiştirilen deneme materyallerinde klasik metotla yapılmış olan PRT, YGLT, FSAB ve AW değerleri Çizelge 1 'de verilmiştir. Bu kalite özelliklerinin seçilmesindeki amaç, Glutopik Hızlı Un Kontrol Metodu ile hesaplanan verilerin bu özellikleri tahmin ettiği öne sürüldüğünden, klasik usulde elde edilen veriler ile Glutopik verilerinin kıyaslanmasıdır.

Çizelge 1. Deneme materyallerine ait bazı kalite özellikleri

Table 1. Some quality properties of trial materials

\begin{tabular}{|c|c|c|c|c|c|c|c|c|c|c|}
\hline \multirow[b]{2}{*}{$\begin{array}{l}\text { Genotip } \\
\text { Genotype }\end{array}$} & \multicolumn{2}{|c|}{$\begin{array}{l}\text { Protein oranı } \\
\text { Protein content } \\
\%(\mathrm{w} / \mathrm{w})\end{array}$} & \multicolumn{2}{|c|}{$\begin{array}{c}\text { Sertlik indeksi } \\
\text { Hardness } \\
\text { SKCS }\end{array}$} & \multicolumn{2}{|c|}{$\begin{array}{c}\text { Yaş gluten } \\
\text { Wet gluten } \\
\%(w / w)\end{array}$} & \multicolumn{2}{|c|}{$\begin{array}{c}\text { Su absorbsiyonu } \\
\text { Water absorption } \\
\%(\mathrm{v} / \mathrm{w})\end{array}$} & \multicolumn{2}{|c|}{$\begin{array}{c}\text { Alveograf enerji } \\
\text { Alveograph Energy } \\
* 10^{-4} \mathrm{~J}\end{array}$} \\
\hline & $\begin{array}{l}\text { sulu } \\
\text { irrigation }\end{array}$ & $\begin{array}{l}\text { kuru } \\
d r y\end{array}$ & $\begin{array}{l}\text { sulu } \\
\text { irrigation }\end{array}$ & $\begin{array}{l}\text { kuru } \\
\text { dry }\end{array}$ & $\begin{array}{l}\text { sulu } \\
\text { irrigation }\end{array}$ & $\begin{array}{l}\text { kuru } \\
d r y\end{array}$ & $\begin{array}{l}\text { sulu } \\
\text { irrigation }\end{array}$ & $\begin{array}{l}\text { kuru } \\
\text { dry }\end{array}$ & $\begin{array}{l}\text { sulu } \\
\text { irrigation }\end{array}$ & $\begin{array}{l}\text { kuru } \\
d r y\end{array}$ \\
\hline Bayındır & $14.5^{a}$ & $13.8^{\mathrm{ab}}$ & $85.9^{a}$ & $69.8^{a}$ & $38.9^{a}$ & $37.0^{\mathrm{ab}}$ & $66.4^{a}$ & $66.7^{a}$ & $189.0^{\mathrm{bc}}$ & $222.2^{b}$ \\
\hline Bezostaya & $12.8^{\text {ef }}$ & $13.0^{\mathrm{cd}}$ & $59.2^{\text {de }}$ & $48.1^{\mathrm{cf}}$ & $34.4^{\text {de }}$ & $34.9^{\mathrm{cd}}$ & $60.6^{e}$ & $59.7^{\text {de }}$ & $155.0^{\mathrm{df}}$ & $171.5^{\text {de }}$ \\
\hline Bozkır & $13.8^{b}$ & $14.2^{\mathrm{a}}$ & $45.0^{f}$ & $40.7^{\text {ef }}$ & $37.1^{b}$ & $38.1^{\mathrm{a}}$ & $60.9^{\text {de }}$ & $60.7^{\mathrm{cd}}$ & $224.3^{a}$ & $212.2^{\mathrm{bc}}$ \\
\hline Buhara & $13.5^{b c}$ & $13.4^{b c}$ & $65.2^{\mathrm{cd}}$ & $59.1^{\mathrm{ac}}$ & $36.4^{b c}$ & $36.0^{b c}$ & $61.0^{\text {ce }}$ & $58.8^{\text {ef }}$ & $208.0^{\mathrm{ab}}$ & $172.7^{\text {de }}$ \\
\hline Hara & $13.0^{\mathrm{df}}$ & $12.6^{\text {de }}$ & $65.6^{\mathrm{cd}}$ & $42.7^{\mathrm{df}}$ & $34.9^{\text {ce }}$ & $33.7^{\mathrm{de}}$ & $61.7^{\mathrm{cd}}$ & $61.1^{c}$ & $211.5^{a}$ & $237.5^{b}$ \\
\hline İkonya & $12.0^{\mathrm{g}}$ & $12.2^{\mathrm{e}}$ & $65.6^{\mathrm{cd}}$ & $55.7^{\mathrm{ad}}$ & $32.3^{f}$ & $32.7^{\text {ef }}$ & $58.6^{f}$ & $57.6^{f}$ & $150.5^{\text {ef }}$ & $162.2^{\mathrm{e}}$ \\
\hline Kilistra & $13.1^{\mathrm{cf}}$ & $12.9^{\mathrm{cd}}$ & $54.5^{\text {ef }}$ & $49.0^{\text {cf }}$ & $35.3^{\mathrm{cd}}$ & $34.7^{c d}$ & $61.8^{b c}$ & $60.9^{\mathrm{cd}}$ & $212.5^{a}$ & $227.2^{\mathrm{b}}$ \\
\hline Meke & $12.9^{\mathrm{df}}$ & $12.4^{\mathrm{de}}$ & $53.6^{\mathrm{ef}}$ & $48.6^{\mathrm{cf}}$ & $34.6^{\text {de }}$ & $32.9^{\text {ef }}$ & $57.0^{\mathrm{g}}$ & $55.4^{\mathrm{g}}$ & $172.3^{\mathrm{cd}}$ & $196.5^{c d}$ \\
\hline Selçuklu & $13.3^{\mathrm{bd}}$ & $13.0^{\mathrm{cd}}$ & $65.7^{\mathrm{cd}}$ & $54.1^{\text {be }}$ & $34.7^{\text {de }}$ & $34.1^{\text {de }}$ & $62.5^{b}$ & $62.8^{b}$ & $225.3^{a}$ & $283.0^{\mathrm{a}}$ \\
\hline Şehzade & $13.2^{\text {ce }}$ & $14.0^{\mathrm{ab}}$ & $46.0^{f}$ & $39.3^{f}$ & $33.8^{e}$ & $31.7^{f}$ & $55.7^{h}$ & $54.9^{g}$ & $140.3^{f}$ & $163.7^{e}$ \\
\hline Taner & $13.4^{\mathrm{bd}}$ & $13.8^{\mathrm{ab}}$ & $79.1^{\mathrm{ab}}$ & $64.7^{\mathrm{ab}}$ & $35.0^{\text {ce }}$ & $36.2^{b c}$ & $61.8^{b c}$ & $61.7^{b c}$ & $212.8^{\mathrm{a}}$ & $236.2^{\mathrm{b}}$ \\
\hline Tuğra & $12.9^{\mathrm{df}}$ & $13.1^{\mathrm{cd}}$ & $70.9^{b c}$ & $47.9^{c f}$ & $34.0^{\text {de }}$ & $34.1^{\text {de }}$ & $59.1^{f}$ & $57.8^{f}$ & $152.0^{\mathrm{ef}}$ & $187.2^{\text {ce }}$ \\
\hline Yavuz & $12.7^{f}$ & $13.3^{b c}$ & $73.1^{b c}$ & $50.4^{\mathrm{bf}}$ & $34.4^{\mathrm{de}}$ & $35.8^{b c}$ & $57.7^{g}$ & $56.2^{\mathrm{g}}$ & $169.8^{\mathrm{ce}}$ & $212.2^{\mathrm{bc}}$ \\
\hline $\begin{array}{l}\text { Ortalama } \\
\text { mean }\end{array}$ & 13.2 & 13.2 & 63.8 & 51.6 & 35 & 34.8 & 60.3 & 59.6 & 186.3 & 206.5 \\
\hline CV(\%) & 2.5 & 3.3 & 11.1 & 12.3 & 2.9 & 3.3 & 0.9 & 1.5 & 6.9 & 8.6 \\
\hline LSD(\%0.05) & 0.5 & 0.6 & 10.4 & 14.3 & 1.4 & 1.6 & 0.8 & 1.3 & 19.4 & 50.7 \\
\hline Genotip genotype & $* *$ & $* *$ & $* *$ & $* *$ & $* *$ & $* *$ & $* *$ & $* *$ & $* *$ & $* *$ \\
\hline $\begin{array}{l}\text { Yıllar } \\
\text { years }\end{array}$ & $* *$ & öd & $* *$ & öd & öd & öd & $*$ & $*$ & $* *$ & $* *$ \\
\hline
\end{tabular}

\section{Glutopik verileri}

AM

Glutopik diyagramının maksimum pik yapmadan 15 s önceki tork değeri GPU olarak ölçülmektedir. AM değeri iki yıl ortalaması sulu lokasyonda 28.2 kuru da ise 23.8 olarak belirlenmiştir. Genotiplerden suluda Bayındır 43.8 ile en yüksek, Şehzade genotipi ise 19.5 ile en düşük değeri almıştır. Kuru lokasyonda ise Bayındır 34.0 ile ilk sırada, Şehzade genotipi 20.0 ile son sırada yer almıştır. Yapılan varyans analizinde AM değeri genotipler arasında $\mathrm{P}<0.01$ düzeyinde önemli iken yıllar arasındaki farkın suluda $\mathrm{P}<0.01$ önemli ve kuru lokasyonda önemsiz olduğu belirlenmiştir. Genotiplerin AM değeri bakımından lokasyon değerlerinde de farklılıklar olduğu Çizelge 2'de görülmektedir. Bu bulgulara göre AM değerinin genetik etkinin yanında çevre şartlarından da etkilendiği söylenebilir. AM değeri ile protein arasında $r=0.2901 \mathrm{P}<0.01$, SRT ile $r=$ $0.2401 P<0.05$, YGLT ile $r=0.3757 P<0.01$, FSAB ile $r=0.5579 P<0.01, A W$ arasında ise $r=0.3580 P$ $<0.01$ pozitif ve önemli korelasyon olduğu bulunmuştur (Çizelge 3). Karaduman ve ark. (2019), AM ile SRT arasında $r=0.3930 P<0.05$ korelasyon bulunduğunu, yine Karaduman ve ark. (2015) yılında yaptığı çalışmada AM değerinin 11.8 ile 41.0 arasında değiştiğini, tane proteini ve sertlik değeri ile $\mathrm{P}<0.01$ düzeyinde pozitif 
korelasyon olduğunu belirtmiştir. Güçbilmez ve ark. (2019) yaptıkları çalışmada AM değerinin 14 ile 36 arasında değiştiğini ve tane sertliği ile $P$ $<0.01$ önemli pozitif korelasyon verdiğini belirtmiştir. Bouchra ve ark. (2017) yılındaki çalışmalarında Glutopik AM değeri ile gluten kalitesi arasında pozitif önemli korelasyon olduğunu belirtmişlerdir. $\mathrm{Bu}$ sonuçlar doğrultusunda AM değerinin yüksek olması gluten kalitesinin yüksek olduğuna işaret etmektedir. Sulu lokasyonda AM değerine göre sırasıyla Bayındır, Buhara, Bozkır, Selçuklu, Kilistra, Taner ilk sıralarda yer alırken; kuru lokasyonda ise Bayındır, Kilistra, Selçuklu, Taner, Hara, ikonya ilk sıralarda yer almıştır. Bozkır çeşidi suluda ilk üçte yer alırken, kuru lokasyonda 21.0 AM değeri ile alt sıralarda yer almıştır. Bozkır çeşidinin AM değeri açısından gluten kalitesinin çevreden diğer genotiplere göre fazla etkilendiği söylenebilir.

\section{$B E M$}

Glutopik diyagramının glutenin toparlanma sürecindeki maksimum tork değeri GPU olarak ölçülmektedir. BEM değeri iki yıl ortalaması sulu lokasyonda 68, kuruda ise 62.5 olarak belirlenmiştir. Genotiplerden sulu ve kuru lokasyonda Bayındır sırasıyla 94.0 ve 85.2 ile en yüksek, Şehzade sulu lokasyonda 56.5 ve kuru lokasyonda Meke genotipi 52.0 ile son sırada yer almıştır (Çizelge 2). Genotiplerin BEM değerinin genotipler ve lokasyonlar arasında farklılık göstermesinde genetik etkinin yanında çevrenin etkisinden de söz edilebilir. Varyans analizinde genotip ve yıllar arasındaki farklılıklar $\mathrm{P}<0.01$ düzeyinde önemli bulunmuştur (Çizelge 2). BEM değeri ile (PRT) arasında $r=0.3054 P<0.01$, SRT ile $r=0.4089 P<0.01$, YGLT ile $r=0.3745 P<0.01, F S A B$ ile $r=0.7665 P<0.01$, AW arasında ise $r=0.2785$ $P<0.01$ pozitif ve önemli korelasyonlar tespit edilmiştir (Çizelge 3). Bu korelasyon değerlerine göre BEM değerinin artması gluten kalitesinin yüksek olmasına işaret etmektedir. Marti ve ark.(2015) buğday unu ile yaptıkları çalışmada BEM değerinin 29.4 ile 43.3 arasında değişen oranlarda bulduklarını ve protein oranı ile $r=0.71$ $\mathrm{P}<0.01$ pozitif ve önemli korelasyon bulduğunu, Bouchra ve ark. (2017) yılında buğday unu ile yaptıkları çalışmada BEM değeri ile protein oranı arasında $\quad r=0.60 \quad P<0.01$ düzeyinde önemli korelasyon katsayısı bulduklarını, Güçbilmez ve ark. (2019) BEM değeri ile protein oranı arasında $0.4776 P<0.05$, sertlik değeri ile ise $0.7607 P<0.01$ düzeyinde önemli korelasyon değeri bulduklarını belirtmişlerdir. Karaduman ve ark. (2015) çalışmalarında 24.5 ile 51.3 arasında BEM değeri tespit ettiklerini belirtmiştir. Bu çalışmada tam buğday unu ile çalıştıklarından BEM değerini daha düşük olarak belirlemişlerdir. Sulu lokasyonda BEM değeri genotiplere göre sırasıyla Bayındır, Buhara, Taner, Bezostaya, Selçuklu, Hara ilk sıralarda yer alırken, kuru lokasyonda ise Bayındır, Selçuklu, Taner, Hara, Kilistra, Bezostaya ilk sıralarda yer almıştır. Buhara genotipi sulu lokasyonda üst sıralarda yer alırken kuru lokasyonda 60 BEM değeri ile alt sıralarda yer almıştır. Buhara çeşidinin BEM değeri açısından gluten kalitesinin çevreden diğer genotiplere göre fazla etkilendiği söylenebilir. 
Çizelge 2. Deneme materyalinin glutopik özellikleri

Table 2. GlutoPeak properties of trial material

\begin{tabular}{|c|c|c|c|c|c|c|c|c|c|c|}
\hline \multirow[b]{2}{*}{$\begin{array}{l}\text { Genotip } \\
\text { genotype }\end{array}$} & \multicolumn{2}{|c|}{$\begin{array}{l}\text { AM } \\
\text { GPU }\end{array}$} & \multicolumn{2}{|c|}{$\begin{array}{l}\text { BEM } \\
\text { GPU }\end{array}$} & \multicolumn{2}{|c|}{$\begin{array}{c}\text { PMT } \\
\mathrm{s}\end{array}$} & \multicolumn{2}{|c|}{$\begin{array}{l}\mathrm{PM} \\
\mathrm{GPU}\end{array}$} & \multicolumn{2}{|c|}{$\begin{array}{c}\text { GPRT } \\
\%(w / w)\end{array}$} \\
\hline & $\begin{array}{c}\text { sulu } \\
\text { irrigation }\end{array}$ & $\begin{array}{l}\text { kuru } \\
\text { dry }\end{array}$ & $\begin{array}{c}\text { sulu } \\
\text { irrigation }\end{array}$ & $\begin{array}{l}\text { kuru } \\
\text { dry }\end{array}$ & $\begin{array}{c}\text { sulu } \\
\text { irrigation }\end{array}$ & $\begin{array}{l}\text { kuru } \\
\text { dry }\end{array}$ & $\begin{array}{c}\text { sulu } \\
\text { irrigation }\end{array}$ & $\begin{array}{l}\text { kuru } \\
\text { dry }\end{array}$ & $\begin{array}{c}\text { sulu } \\
\text { irrigation }\end{array}$ & $\begin{array}{l}\text { kuru } \\
\text { dry }\end{array}$ \\
\hline Bayındır & $43.8^{\mathrm{a}}$ & $34.0^{a}$ & $94.0^{\mathrm{a}}$ & $85.2^{a}$ & $28.8^{g}$ & $29.7^{f}$ & $74.5^{\mathrm{a}}$ & $63.7^{a}$ & $15.8^{\mathrm{a}}$ & $14.5^{a}$ \\
\hline Bezostaya & $21.5^{b c}$ & $21.2^{\text {de }}$ & $69.8^{\mathrm{cd}}$ & $60.2^{\text {de }}$ & $55.5^{f}$ & $63.0^{e}$ & $43.5^{b c}$ & $41.0^{\text {de }}$ & $12.3^{\text {de }}$ & $11.7^{\mathrm{dg}}$ \\
\hline Bozkır & $31.3^{b}$ & $21.0^{\text {de }}$ & $63.5^{\mathrm{ce}}$ & $60.0^{\text {de }}$ & $75.8^{\text {be }}$ & $81.2^{\text {be }}$ & $47.3^{b c}$ & $41.5^{\text {de }}$ & $12.6^{\mathrm{ce}}$ & $12.0^{\mathrm{cg}}$ \\
\hline Buhara & $43.3^{a}$ & $21.7^{\text {de }}$ & $79.8^{b}$ & $60.0^{\text {de }}$ & $91.8^{\mathrm{ab}}$ & $85.2^{\text {be }}$ & $70.0^{\mathrm{a}}$ & $45.5^{\mathrm{cd}}$ & $14.7^{\mathrm{b}}$ & $12.2^{\text {be }}$ \\
\hline Hara & $25.0^{b c}$ & $24.0^{\mathrm{cd}}$ & $68.0^{\mathrm{cd}}$ & $65.0^{\mathrm{bd}}$ & $67.8^{\mathrm{ef}}$ & $100.7^{\mathrm{ac}}$ & $46.5^{b c}$ & $45.5^{\mathrm{cd}}$ & $12.7^{\mathrm{ce}}$ & $12.4^{b c}$ \\
\hline İkonya & $26.0^{\mathrm{bc}}$ & $22.5^{\text {de }}$ & $65.8^{\mathrm{ce}}$ & $59.0^{\mathrm{e}}$ & $72.5^{\mathrm{ce}}$ & $85.7^{\text {be }}$ & $47.0^{\mathrm{bc}}$ & $42.0^{\text {de }}$ & $12.5^{\mathrm{ce}}$ & $11.7^{\mathrm{eg}}$ \\
\hline Kilistra & $29.0^{b c}$ & $29.0^{\mathrm{b}}$ & $64.0^{\text {ce }}$ & $62.5^{\mathrm{ce}}$ & $72.0^{\text {de }}$ & $92.7^{\mathrm{bd}}$ & $50.0^{\mathrm{bc}}$ & $47.7^{b c}$ & $12.8^{\mathrm{cd}}$ & $12.3^{\mathrm{bd}}$ \\
\hline Meke & $24.5^{b c}$ & $21.5^{\text {de }}$ & $61.5^{\mathrm{ce}}$ & $52.0^{f}$ & $98.8^{a}$ & $123.2^{\mathrm{a}}$ & $43.8^{b c}$ & $37.0^{\mathrm{e}}$ & $11.9^{\text {de }}$ & $11.0^{\mathrm{h}}$ \\
\hline Selçuklu & $30.5^{b}$ & $27.5^{b c}$ & $69.3^{\mathrm{cd}}$ & $69.2^{b}$ & $71.3^{\mathrm{df}}$ & $75.2^{\text {ce }}$ & $51.3^{\mathrm{b}}$ & $51.7^{\mathrm{e}}$ & $12.8^{\mathrm{cd}}$ & $12.6^{b}$ \\
\hline Şehzade & $19.5^{c}$ & $20.0^{\mathrm{e}}$ & $56.5^{e}$ & $57.2^{\text {ef }}$ & $88.5^{\mathrm{ac}}$ & $96.0^{\mathrm{ad}}$ & $39.5^{c}$ & $38.7^{e}$ & $11.7^{\mathrm{e}}$ & $11.5^{\mathrm{gh}}$ \\
\hline Taner & $27.0^{b c}$ & $24.7^{c d}$ & $70.8^{b c}$ & $66.2^{b c}$ & $59.8^{\mathrm{ef}}$ & $72.0^{\text {de }}$ & $52.8^{b}$ & $48.7^{b c}$ & $13.3^{c}$ & $12.5^{b c}$ \\
\hline Tuğra & $22.5^{b c}$ & $21.0^{\mathrm{de}}$ & $60.3^{\mathrm{de}}$ & $58.5^{\mathrm{e}}$ & $93.3^{a}$ & $107.7^{\mathrm{ab}}$ & $46.3^{b c}$ & $39.2^{\mathrm{e}}$ & $12.2^{\mathrm{de}}$ & $12.1^{\mathrm{bf}}$ \\
\hline Yavuz & $23.0^{\mathrm{bc}}$ & $21.0^{\text {de }}$ & $61.3^{\text {ce }}$ & $57.7^{\mathrm{e}}$ & $84.8^{\mathrm{ad}}$ & $106.7^{\mathrm{ab}}$ & $48.0^{b c}$ & $42.0^{\mathrm{e}}$ & $12.1^{\text {de }}$ & $11.5^{\text {fh }}$ \\
\hline $\begin{array}{c}\text { Ortalama } \\
\text { mean }\end{array}$ & 28.2 & 23.8 & 68 & 62.5 & 73.8 & 86.1 & 50.7 & 45 & 12.8 & 12.2 \\
\hline CV(\%) & 7.6 & 11.1 & 9.7 & 6 & 10.5 & 7.2 & 11.4 & 6.8 & 1.2 & 3.4 \\
\hline LSD(\%0.05) & 10.6 & 3.8 & 9.48 & 5.4 & 16.3 & 5.3 & 10.5 & 5.3 & 5.5 & 0.6 \\
\hline $\begin{array}{l}\text { Genotip } \\
\text { genotype }\end{array}$ & $* *$ & $* *$ & $* *$ & $* *$ & $* *$ & $* *$ & $* *$ & $* *$ & $* *$ & $* *$ \\
\hline $\begin{array}{c}\text { YIl } \\
\text { year }\end{array}$ & $* *$ & öd & $* *$ & $* *$ & $* *$ & $* *$ & $* *$ & $* *$ & $* *$ & $* *$ \\
\hline
\end{tabular}

Çizelge 2. Devamı

Table 2. (continued)

\begin{tabular}{|c|c|c|c|c|c|c|c|c|c|c|}
\hline \multirow[b]{2}{*}{$\begin{array}{l}\text { Genotip } \\
\text { Genotype }\end{array}$} & \multicolumn{2}{|c|}{$\begin{array}{c}\text { GGLT } \\
\%(w / w)\end{array}$} & \multicolumn{2}{|c|}{$\begin{array}{c}\mathrm{GW} \\
* 10^{-4} \mathrm{~J}\end{array}$} & \multicolumn{2}{|c|}{$\begin{array}{c}\text { GSAB } \\
\%(v / w)\end{array}$} & \multicolumn{2}{|c|}{$\begin{array}{c}\text { S.Enerji } \\
\text { GPU }\end{array}$} & \multicolumn{2}{|c|}{$\begin{array}{c}\text { Ag.Enerji } \\
\text { GPU }\end{array}$} \\
\hline & $\begin{array}{c}\text { sulu } \\
\text { irrigation }\end{array}$ & $\begin{array}{c}\text { kuru } \\
d r y\end{array}$ & $\begin{array}{c}\text { sulu } \\
\text { irrigation }\end{array}$ & $\begin{array}{c}\text { kuru } \\
\text { dry }\end{array}$ & $\begin{array}{c}\text { sulu } \\
\text { irrigation }\end{array}$ & $\begin{array}{c}\text { kuru } \\
d r y\end{array}$ & $\begin{array}{c}\text { sulu } \\
\text { irrigation }\end{array}$ & $\begin{array}{c}\text { kuru } \\
\text { dry }\end{array}$ & $\begin{array}{c}\text { sulu } \\
\text { irrigation }\end{array}$ & $\begin{array}{c}\text { kuru } \\
\text { dry }\end{array}$ \\
\hline Bayındır & $38.5^{\mathrm{a}}$ & $35.2^{\mathrm{a}}$ & $631.8 \mathrm{a}$ & $592.7^{a}$ & $72.3^{a}$ & $71.5^{a}$ & $1313.0^{\mathrm{a}}$ & $1258.1^{\mathrm{a}}$ & $2272.3^{a}$ & $2052 .^{a}$ \\
\hline Bezostaya & $28.1^{c}$ & $26.6^{\text {de }}$ & $356.8 \mathrm{dg}$ & $327.0^{\text {ef }}$ & $62.1^{c}$ & $61.0^{\text {ef }}$ & $683.9^{\mathrm{ac}}$ & $717.8^{b}$ & $1403.4^{\text {ce }}$ & $1323.8^{\mathrm{ef}}$ \\
\hline Bozkır & $29.4^{b c}$ & $27.9^{\mathrm{cd}}$ & $379.5 \mathrm{cf}$ & $357.7^{\text {ce }}$ & $62.7^{c}$ & $61.6^{\mathrm{df}}$ & $946.7^{a}$ & $139.0^{c}$ & $1664.4^{c}$ & $1377.3^{\mathrm{e}}$ \\
\hline Buhara & $35.7^{\mathrm{ab}}$ & $28.3^{\mathrm{bd}}$ & $427.5 b c$ & $348.2^{\mathrm{df}}$ & $63.5^{b c}$ & $62.1^{\mathrm{df}}$ & $221.3^{b c}$ & $201.8^{c}$ & $1644.0^{c d}$ & $1449.7^{\text {de }}$ \\
\hline Hara & $29.2^{\mathrm{bc}}$ & $28.3^{\mathrm{bd}}$ & $393.8 \mathrm{bd}$ & $376.7^{\text {be }}$ & $62.6^{c}$ & $62.6^{\mathrm{ce}}$ & $814.5^{a b}$ & $183.9^{c}$ & $1581.5^{c d}$ & $1472.8^{\mathrm{ce}}$ \\
\hline İkonya & $28.8^{\mathrm{bc}}$ & $26.7^{\text {de }}$ & 385.8ce & $332.0^{\text {ef }}$ & $62.2^{c}$ & $61.6^{\mathrm{df}}$ & $183.6^{b c}$ & $187.2^{\mathrm{c}}$ & $1511.2^{\mathrm{ce}}$ & $1409.9^{\mathrm{e}}$ \\
\hline Kilistra & $29.5^{b c}$ & $28.3^{\mathrm{bd}}$ & $405 b d$ & $434.0^{b}$ & $64.2^{\mathrm{bc}}$ & $63.6^{\mathrm{bd}}$ & $153.6^{c}$ & $159.2^{c}$ & $2046.3^{a b}$ & $1623.2^{b c}$ \\
\hline Meke & $27.6^{c}$ & $24.3^{c}$ & 331.3fh & $215.2^{\mathrm{g}}$ & $62.1^{c}$ & $58.6^{g}$ & $272.5^{b c}$ & $137.4^{c}$ & $1368.5^{\mathrm{ce}}$ & $1199.2^{f}$ \\
\hline Selçuklu & $30.4^{b c}$ & $29.9^{b}$ & $419 b c$ & $419.5^{b c}$ & $65.2^{b}$ & $65.7^{b}$ & $1005.4^{a}$ & $952.2^{\mathrm{ab}}$ & $1641.9^{\mathrm{cd}}$ & $1626.3^{b}$ \\
\hline Şehzade & $25.7^{c}$ & $25.2^{c}$ & $277.3 \mathrm{~h}$ & $294.0^{f}$ & $59.8^{d}$ & $60.1^{\mathrm{fg}}$ & $121.1^{\mathrm{c}}$ & $645.9^{b c}$ & $1276.8^{\text {de }}$ & $1324.3^{\text {ef }}$ \\
\hline Taner & $38.8^{a}$ & $29.7^{b c}$ & $444.5 b$ & $406.7^{\text {bd }}$ & $65.6^{b}$ & $64.5^{b c}$ & $196.2^{b c}$ & $185.1^{\mathrm{c}}$ & $1704.2^{b c}$ & $1576.5^{\mathrm{bd}}$ \\
\hline Tuğra & $27.8^{c}$ & $26.8^{\text {de }}$ & 315.8gh & $294.2^{f}$ & $62.5^{c}$ & $60.7^{\mathrm{eg}}$ & $160.6^{c}$ & $147.4^{c}$ & $1440.7^{\text {ce }}$ & $1350.6^{\mathrm{ef}}$ \\
\hline Yavuz & $27.7^{c}$ & $26.5^{\text {de }}$ & $338.3 \mathrm{eg}$ & $295.0^{f}$ & $62.7^{c}$ & $60.4^{f g}$ & $726.7^{\mathrm{ac}}$ & $141.4^{c}$ & $1178.8^{\mathrm{e}}$ & $1339.2^{\mathrm{ef}}$ \\
\hline $\begin{array}{c}\text { Ortalama } \\
\text { mean }\end{array}$ & 30.5 & 28 & 392.7 & 361 & 63.6 & 62.7 & 522.5 & 389 & 1594.5 & 1471.2 \\
\hline CV(\%) & 0.7 & 4.7 & 54.1 & 11.9 & 2.2 & 2.3 & 13.7 & 24.2 & 15.1 & 7.2 \\
\hline LSD(\%0.05) & 9.8 & 1.9 & 9.6 & 61.7 & 2.4 & 2.1 & 561.2 & 508.4 & 371 & 393.2 \\
\hline $\begin{array}{l}\text { Genotip } \\
\text { genotype }\end{array}$ & $* *$ & $* *$ & $* *$ & $* *$ & $* *$ & $* *$ & $* *$ & $* *$ & $* *$ & $* *$ \\
\hline $\begin{array}{l}\text { Yillar } \\
\text { years }\end{array}$ & öd & $* *$ & $* *$ & $* *$ & $*$ & $* *$ & öd & öd & $* *$ & $* *$ \\
\hline
\end{tabular}

a-j: aynı sütundaki üssel değerler aralarındaki anlamlı farklılığı göstermektedir (Values in the same column with different superscripts indicate a statiscally significant difference).**: \%1 seviyesinde farklılık ${ }^{*} \% 5$ seviyesinde farklılık. Öd.; Önemli değil (*;Significance between varieties at 1\%,** 5\%, ö.d; not important).GPU: Glutopik Unit (GlutoPeak Unite). AM: maksimum torktan 15 s önceki tork (torque $15 \mathrm{~s}$ before maximum torque), BEM: Glutenin toparlanma sürecindeki maksimum tork (Maximum torque), PM:Maksimum torkdan $15 \mathrm{~s}$ sonraki tork (torque $15 \mathrm{~s}$ after maximum torque). PMT: Maksimum torka kadar geçen süre (peak maximum time). GPRT: Glutopik Protein Oranı (GlutoPeak protein content), GGLT: Glutopik yaş gluten (Glutopeak wet gluten), GW: Glutopik W enerji değeri (GlutoPeak W energy). GSAB: Glutopik su absorbsiyon (GlutoPeak water absorbtion). S.enerji: Startup enerji değeri (Startup Energy). Ag.Enerji: Agregasyon enerji değeri (Aggregation Energy). s:Saniye (second) LSD: Asgari önemli fark (LSD: Least significant differences), CV: Değişim katsayısı (CV: Coefficient of variation) 
PMT

Glutopik diyagramının başlangıcından maksimum torka kadar geçen süre saniye olarak ölçülmektedir. PMT değerinin sulu lokasyonda iki yıl ortalaması $73.8 \mathrm{~s}$, kuruda ise $86.1 \mathrm{~s}$ olarak belirlenmiştir. PMT değeri bakımından genotiplerden sulu ve kuru lokasyonda Meke genotipi sırasıyla 98.8 s ve 123.2 s ile en yüksek, Bayındır genotipi ise 28.8 s ve 29.7 s ile son sırada yer almıştır (Çizelge 2). PMT değerinin genotip ve yıllar arasındaki farklııkları $\mathrm{P}<0.01$ düzeyinde önemli bulunmuştur (Çizelge 2). PMT değeri ile PRT arasında $r=-0.3583 P<0.01$, SRT ile $r=-0.3084$ $P<0.01$, $Y$ GLT ile $r=-0.3566 P<0.01$, FSAB ile $r=$ $0.6385 P<0.01$ negatif ve önemli korelasyonlar tespit edilmiştir (Çizelge 3). İncelenen korelasyon değerlerine göre PMT değerinin artması gluten kalitesinin düşük olmasına işaret etmektedir. Rakita ve ark., (2018) yaptıkları çalışmada PMT değeri ile protein oranı arasında $r=-0.855 P<0.01$, YGLT ile $r=-0.841 P<0.01$, FSAB ile $r=-0.798$ $\mathrm{P}<0.01$ düzeyinde önemli ve negatif korelasyon olduğunu belirtmiştir. Güçbilmez ve ark. (2019) PMT değeri ile PRT arasında $r=-0.2101$, SRT ile ise $r=-0.6659 \quad P<0.01$ düzeyinde önemli negatif korelasyon olduğunu belirtmişlerdir. Wang ve ark. (2018) ekmeklik buğdayla ilgili yaptıkları çalışmada PMT değerinin 41.3 ile $92.3 \mathrm{~s}$ arasında değiştiğini belirtmişlerdir. Sonuçlar, bu çalışmadaki bulgularla benzerlik göstermektedir. Sulu lokasyonda genotiplerin PMT değerine göre yüksek olanlar sırasıyla; Meke, Tuğra, Buhara, Şehzade, Yavuz, Bozkır kuru lokasyonda ise Meke, Tuğra, Yavuz, Hara, Şehzade, Kilistra olarak sıralanmışlardır. PMT değerine göre Meke, Tuğra, Yavuz genotiplerinin gluten kalitesinin diğer genotiplere göre daha zayıf olduklarını söyleyebiliriz.

\section{$P M$}

Glutopik diyagramının maksimum torktan $15 \mathrm{~s}$ sonraki tork değeri GPU olarak ölçülmektedir. PM değerinin iki yıl ortalaması sulu lokasyonda 50.7, kuruda ise 45.0 olarak belirlenmiştir. PM değeri bakımından genotiplerden suluda Bayındır 74.5 ile en yüksek, Şehzade genotipi ise 39.5 ile son sırada yer almıştır. Kuru lokasyonda ise Bayındır 63.7 ile ilk sırada olurken, Meke genotipi 37.0 ile son sırada yer almıştır. Yapılan varyans analizinde PM değerinin genotipler ve yıllar arasında $\mathrm{P}<0.01$ düzeyinde önemli olduğu belirlenmiştir (Çizelge 2). $P M$ değeri ile PRT arasında $r=0.3202 P<0.01$, SRT ile $r=0.3916 P<0.01$, YGLT ile $r=0.4065$ $\mathrm{P}<0.01$, FSAB ile $r=0.6777 \mathrm{P}<0.01, \mathrm{AW}$ arasında ise $r=0.3197 \mathrm{P}<0.01$ pozitif ve önemli korelasyon olduğu bulunmuştur (Çizelge 3 ). Karaduman ve ark. (2015) PM ile protein oranı arasında $r=0.22 P$ $<0.05$ korelasyon bulunduğunu, PM değerinin 19.0 ile 41.5 arasında değiştiğini, Güçbilmez ve ark. (2019) yaptıkları çalışmada PM değerinin 28 ile 56 arasında değiştiğini ve tane sertliği ile $r=$ $0.7909 \mathrm{P}<0.01$ önemli pozitif korelasyon verdiğini belirtmiştir. Bu sonuçlar doğrultusunda PM değerinin yüksek olması gluten kalitesinin yüksek olduğuna işaret etmektedir. Sulu lokasyonda PM değerine göre sırasıyla; Bayındır, Buhara, Taner, Selçuklu, Kilistra ilk sıralarda yer alırken, kuru lokasyonda ise Bayındır, Selçuklu, Taner, Kilistra, Buhara ve Hara ilk sıralarda yer almıştır.

\section{GPRT}

Deneme örneklerinin Glutopik cihazının hesapladığı protein (GPRT) oranları, Dumas yöntemi ile yapılmış (PRT) oranlar ile kıyaslama yapılarak değerlendirilmiştir. Dumas yöntemi ile yapılan protein oranları iki yıl ortalaması sulu lokasyonda ve kuru lokasyonda \%13.2 (w/w) olup aynı değere sahip olmuştur. Genotipler arasındaki farklılıklar $\mathrm{P}<0.01$ düzeyinde önemli iken yıllar arasında sulu lokasyonda $\mathrm{P}<0.01$ düzeyinde önemli, kuru lokasyonda ise önemsiz olduğu belirlenmiştir (Çizelge 1). Glutopik cihazı ile hesaplanmış protein oranlarının (GPRT) iki yıl ortalaması sulu lokasyonda \%12.8 (w/w), kuru lokasyonda ise \%12.2 (w/w) olarak belirlenmiştir. Sulu ve kuru lokasyonda genotipler ve yıllar arasındaki farklılıklar $\mathrm{P}<0.01$ düzeyinde önemli bulunmuştur. 
Çizelge 3. Özellikler arası korelasyon katsayıları $(r)(n=104)$

Table 3. Correlation coefficients between properties $(r)(n=104)$

\begin{tabular}{|c|c|c|c|c|c|c|c|c|c|c|c|c|c|c|}
\hline & PRT & SRT & YGLT & FSAB & AW & AM & BEM & PMT & PM & GPRT & GGLT & GW & GSAB & S.enerji \\
\hline SRT & 0.073 & & & & & & & & & & & & & \\
\hline YGLT & 0.747 & 0.198 & & & & & & & & & & & & \\
\hline FSAB & 0.375 & 0.376 & 0.552 & & & & & & & & & & & \\
\hline AW & 0.152 & -0.074 & 0.262 & 0.492 & & & & & & & & & & \\
\hline AM & 0.290 & 0.240 & 0.376 & 0.558 & 0.358 & & & & & & & & & \\
\hline BEM & 0.305 & 0.409 & 0.375 & 0.767 & 0.279 & 0.759 & & & & & & & & \\
\hline PMT & -0.358 & -0.308 & -0.357 & -0.639 & 0.087 & -0.206 & -0.529 & & & & & & & \\
\hline PM & 0.320 & 0.392 & 0.407 & 0.678 & 0.320 & 0.870 & 0.905 & -0.371 & & & & & & \\
\hline GPRT & 0.359 & 0.408 & 0.447 & 0.752 & 0.305 & 0.835 & 0.938 & -0.466 & 0.958 & & & & & \\
\hline GGLT & 0.299 & 0.421 & 0.351 & 0.627 & 0.311 & 0.649 & 0.742 & -0.387 & 0.764 & 0.780 & & & & \\
\hline GW & 0.343 & 0.402 & 0.435 & 0.856 & 0.392 & 0.688 & 0.874 & -0.608 & 0.835 & 0.876 & 0.710 & & & \\
\hline GSAB & 0.373 & 0.483 & 0.432 & 0.828 & 0.368 & 0.655 & 0.816 & -0.591 & 0.783 & 0.816 & 0.677 & 0.919 & & \\
\hline S.enerji & 0.262 & 0.242 & 0.220 & 0.444 & 0.164 & 0.331 & 0.384 & -0.532 & 0.270 & 0.321 & 0.214 & 0.379 & 0.451 & \\
\hline Ag.enerji & 0.283 & 0.252 & 0.343 & 0.683 & 0.405 & 0.669 & 0.703 & -0.386 & 0.734 & 0.750 & 0.611 & 0.797 & 0.775 & 0.251 \\
\hline
\end{tabular}

$0.1979<r>0.2512 ; \mathrm{P}<0.05$ düzeyinde önemli, $0.2513<\mathrm{r}>1.00 \mathrm{P}<0.01$ düzeyinde önemli $(0.1979<r>0.2512$ significant at $P<0.05$ level, $0.2513<r>1.00$ significant at $P<0.01$ level).

GPRT ile PRT arasında $r=0.3592 \mathrm{P}<0.01$, SRT ile $r=$ $0.4083 \mathrm{P}<0.01$, YGLT ile $r=0.4470 \mathrm{P}<0.01$, FSAB ile $r=0.7524 P<0.01$, AW arasında ise $r=0.3051$ $P<0.01$ pozitif ve önemli korelasyon olduğu bulunmuştur (Çizelge 3). GPRT ile PRT arasındaki regresyon ilişkisi ise Şekil 1a'da görüldüğü gibidir. Regresyon eşitliği $\mathrm{P}<0.01$ düzeyinde önemli bulunmuştur. Regresyonun daha doğrusal olması beklenirken dağııım fazla olmuştur.

Protein oranı (PRT) bakımından sulu lokasyonda \%14.5 (w/w) ile Bayındır ilk sırada, $\% 12.0(\mathrm{w} / \mathrm{w})$ ile ikonya son sırada yer almıştır. Kuru lokasyonda ise \%14.2 (w/w) ile Bozkır ilk sırada, \%12.2 (w/w) ile Ikonya son sırada yer almıştır, diğer genotiplerin değerleri ise bu değerler arasında dağılım göstermiştir (Çizelge 1). GPRT'ye göre ise sulu ve kuru lokasyonda Bayındır sırasıyla \%15.8 (w/w) ve \%14.5 (w/w) ile ilk sırada yer alırken, suluda Şehzade $\% 11.7(\mathrm{w} / \mathrm{w})$ ve kuruda Meke \%11.0 (w/w) ile son sırada yer almışlardır (Çizelge 2). GPRT ile ölçülen protein değerleri ile Dumas yöntemi (PRT) ile ölçülen değerler arasında bir paralellik söz konusudur. Bayındır genotipinin protein oranı her iki yöntemle de yüksek değere sahip iken Yavuz genotipinin her iki yöntemle de düşük değerlere sahip olduğu görülmektedir. Islah çalışmalarında protein oranın değerlendirilmesinde Glutopik cihazından elde edilen protein oranlarının kullanılabileceği düşüncesi oluşmuştur. Güçbilmez ve ark. (2019), Hızlı Un Kontrol Metodu ile yapmış oldukları Glutopik çalışmasında PRT ile GPRT arasında $r=0.4439 \mathrm{P}<0.05$ düzeyinde önemli ilişki olduğunu, denemenin PRT ortalamasını \%12.5 $(\mathrm{w} / \mathrm{w})$, GPRT ortalamasını ise $\% 11.6(\mathrm{w} / \mathrm{w})$ olarak bulduklarını belirtmişlerdir. Şahin ve ark. (2013) yapılan bir çalışmada en düşük protein oranını $\% 10.4(w / w)$, en yükseğini $\% 16.9(w / w)$, ortalama değeri ise $\% 14.0 \quad(\mathrm{w} / \mathrm{w})$ olarak bulduklarını belirtmişlerdir. Elde edilen veriler bu çalışma ile benzerlik göstermektedir.

\section{GGLT}

Deneme örneklerinin YGLT analizleri Gluten yıkama cihazı ile yapılmış ve glutopik cihazının hesapladığı yaş gluten (GGLT) oranları ile kıyaslama yapılarak değerlendirilmiştir. Klasik yöntemle yapılan YGLT oranları iki yıl ortalaması sulu lokasyonda $\% 35.0(\mathrm{w} / \mathrm{w})$, kuru lokasyonda ise \%34.8 (w/w) olarak belirlenmiştir. Genotipler arasındaki farklılıklar $\mathrm{P}<0.01$ düzeyinde önemli iken yıllar ve lokasyonlar arasında ise önemsiz olduğu belirlenmiştir (Çizelge 1). Glutopik cihazı ile GGLT oranları iki yıl ortalaması sulu lokasyonda $\% 30.5(\mathrm{w} / \mathrm{w})$, kuru lokasyonda ise \%28.0 (w/w) olarak belirlenmiştir. Sulu ve kuru lokasyonda genotipler arasındaki farklılıklar $\mathrm{P}<0.01$ düzeyinde önemli, yıllar arasındaki farklılıklar ise sulu lokasyonda önemsiz, kuru lokasyonda ise $\mathrm{P}<0.01$ düzeyinde önemli bulunmuştur (Çizelge 2). GGLT ile PRT arasında $r=0.2987 P<0.01$, SRT ile $r=$ $0.4211 P<0.01$, YGLT ile $r=0.3506 P<0.01$, FSAB ile $r=0.6272 \quad P<0.01$, AW arasinda ise $r=0.3108$ 
$\mathrm{P}<0.01$ pozitif ve önemli korelasyon olduğu bulunmuştur (Çizelge 3). GGLT ile YGLT arasındaki regresyon ilişkisi ise Şekil 1a'da görüldüğü gibidir.
Regresyon eşitliği $\mathrm{P}<0.01$ düzeyinde önemli bulunmuştur. Regresyonun daha doğrusal olması beklenirken dağılım fazla olmuştur.

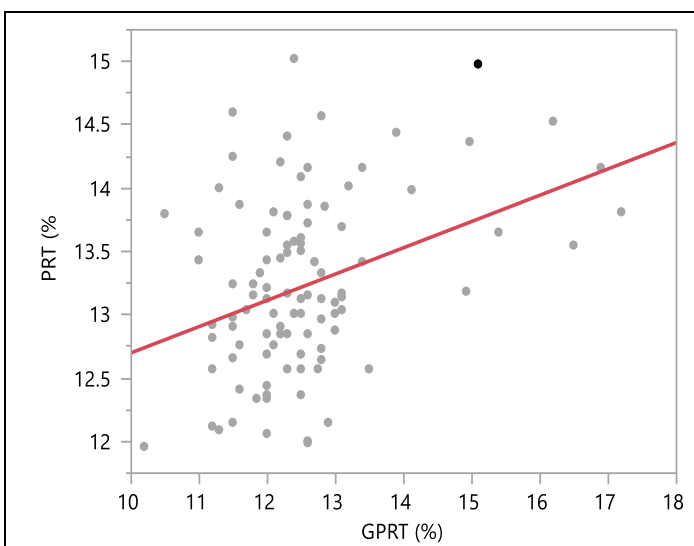

a. $P R T(\%)=10.6+0.207^{*} G P R T \%, P<0.01$ $\left(R^{2}: 0.13\right)$

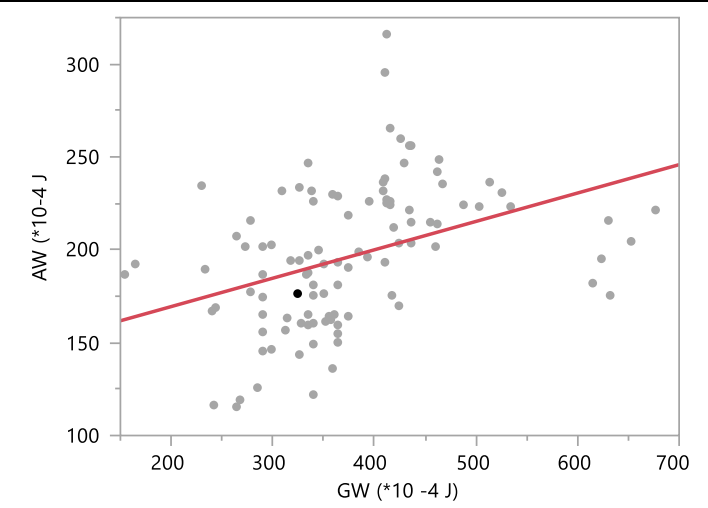

C. $A W^{*} 10^{-4} \mathrm{~J}=138.8+0.152 * G W * 10^{-4} \mathrm{~J}, P<0.01$ $\left(R^{2}: 0.16\right)$

Şekil 1. a.Tane proteini \%(w/w) (PRT) ve Glutopik protein \%(w/w) (GPRT), b. Yaş Gluten \%(w/w) (YGLT) ve Glutopik Gluten $\%(w / w)(G G L T)$, c. Alveograf enerji $\left(* 10^{-4} \mathrm{~J}\right)(A W)$ ve Glutopik W enerji( $\left.{ }^{*} 10^{-4} \mathrm{~J}\right)(\mathrm{GW}) \mathrm{d}$. Farinograf su absorbsiyonu (FSAB) \%(w/w) ve Glutopik su absorbsiyonu (GSAB) \%(w/w) regresyon grafiği ve regresyon eşitliği

Figure 1. a. Regression graph and regression equation of a. grain protein $(P R T) \%(w / w)$ and GlutoPeak protein (GPRT) \%(w/w), b. Wet Gluten (YGLT) \%(W/W) and GlutoPeak Gluten (GGLT) c. Alveograph energy (AW) and GlutoPeak W energy $(G W) d$. Farinograph water absorption $(F S A B) \%(v / w)$ and GlutoPeak water absorption $(G S A B) \%(v / w)$

Genotiplerin YGLT oranı bakımından sulu lokasyonda \%38.9 ile Bayındır ilk sırada, \%32.3 ile ikonya son sırada yer almıştır. Kuru lokasyonda ise \%38.1 ile Bozkır ilk sırada, \%31.7 ile Şehzade son sırada yer almıştır. Diğer genotipler bu değerler arasında dağılım göstermiştir (Çizelge 1). GGLT oranına göre ise sulu ve kuru lokasyonda sırasıyla \%38.8 (w/w) ile Taner ve \%35.2 (w/w) ile Bayındır ilk sırada, \%25.7 (w/w) ile Şehzade ve \%24.3 (w/w) ile Meke son sırada yer almışlardır (Çizelge 2). Glutopik ile ölçülen GGLT değerleri ile YGLT değerleri arasında bir paralellik söz konusudur. Islah çalışmalarında protein oranının değerlendirilmesinde Glutopik cihazından elde edilen protein oranlarının kullanılabileceği düşüncesi oluşmuştur. Güçbilmez ve ark. (2019), Hızlı Un Kontrol Metodu ile yapmış oldukları glutopik çalışmasında GGLT ile YGLT arasında $r=$ $0.6273 \quad P<0.01$ düzeyinde önemli ilişki bulunduğunu belirtmişlerdir. Elde edilen bu veriler diğer araştırmalarla benzerlik göstermektedir.

GW

Denemede örneklerin Alveograf analizleri Alveo PC cihazı ile yapılmış (AW) ve Glutopik cihazının hesapladığı W enerji (GW) oranları ile kıyaslama yapılarak değerlendirilmiştir. Klasik yöntemle yapılan AW değerleri iki yıl ortalaması sulu lokasyonda $186.3\left({ }^{*} 10^{-4} \mathrm{~J}\right)$, kuru lokasyonda 
ise $206.5\left(* 10^{-4} \mathrm{~J}\right)$ olarak belirlenmiştir. Genotipler arasında ve yıllar arasındaki farklııkların $\mathrm{P}<0.01$ düzeyinde önemli olduğu belirlenmiştir (Çizelge 1). Glutopik cihazı ile hesaplanmış GW değerleri ise iki yıl ortalaması olarak sulu lokasyonda 392.7 $\left(* 10^{-4} \mathrm{~J}\right)$, kuru lokasyonda ise $361.0\left(* 10^{-4} \mathrm{~J}\right)$ olarak hesaplanmıştır. Genotipler arasında ve yıllar arasındaki farklılıkların $\mathrm{P}<0.01$ düzeyinde önemli olduğu belirlenmiştir (Çizelge 2). GW ile PRT arasında $r=0.3434 P<0.01$, SRT ile $r=0.4016$ $P<0.01$, YGLT ile $r=0.4348 P<0.01$, FSAB ile $r=$ $0.8560 P<0.01$, AW arasında ise $r=0.3919 P<0.01$ pozitif ve önemli korelasyon olduğu bulunmuştur (Çizelge 3). GW ile AW arasındaki regresyon ilişkisi ise Şekil $1 c^{\prime}$ de görüldüğü gibidir. Regresyon eşitliği $\mathrm{P}<0.01$ düzeyinde önemli bulunmuştur. Regresyon daha doğrusal bir ilişki göstermesine rağmen, bazı genotipler daha geniş bantta dağılım göstermiştir. Genotiplerin AW değeri bakımından sulu lokasyonda $225.3\left({ }^{*} 10^{-4} \mathrm{~J}\right)$ ile Selçuklu ilk sırada, $140.3\left({ }^{*} 10^{-4} \mathrm{~J}\right)$ ile Şehzade son sırada yer almıştır. Kuru lokasyonda ise $283.0\left(* 10^{-4} \mathrm{~J}\right)$ ile ilk sırada Selçuklu, $162.2\left({ }^{*} 10^{-4} \mathrm{~J}\right)$ ile ikonya son sırada yer almıştır. Diğer genotipler bu değerler arasında dağılım göstermiştir (Çizelge 1). GW değerine göre ise sulu ve kuru lokasyonda sırasıyla $631.7\left(* 10^{-4} \mathrm{~J}\right)$ ve $592.7\left(* 10^{-4} \mathrm{~J}\right)$ ile Bayındır ilk sırada yer almıştır. Sulu lokasyonda $277.3\left({ }^{*} 10^{-4} \mathrm{~J}\right)$ ile Şehzade, kuru lokasyonda $215.23\left(* 10^{-4} \mathrm{~J}\right)$ ile Meke son sırada yer almışlardır (Çizelge 2). Sulu lokasyonda Selçuklu, Bozkır, Taner, Kilistra Hara, Buhara istatistiki olarak AW değerlerine göre aynı grupta yer almışlardır (Çizelge 1). Güçbilmez ve ark. (2019), GW ile AW arasında $r=0.7484 P<0.01$ düzeyinde önemli ilişki bulduğunu belirtmişlerdir. $\mathrm{Bu}$ araştırmada elde edilen sonuçlar diğer çalışmalarla paralellik göstermektedir.

\section{GSAB}

Deneme örnekleri farinograf su absorbsiyonu (FSAB) ve glutopik cihazının hesapladığı su absorbsiyonu (GSAB) oranları kıyaslama yapılarak değerlendirilmiştir. Klasik yöntemle yapılan FSAB değerleri iki yıl ortalaması sulu lokasyonda $\%(\mathrm{v} / \mathrm{w}) 60.3$, kuru lokasyonda ise \%59.6 (v/w) olarak belirlenmiştir. Genotipler arasındaki farklılıkların $P<0.01$ düzeyinde önemli, yıllar arasındaki farklılıkların ise $\mathrm{P}<0.05$ düzeyinde önemli olduğu belirlenmiştir (Çizelge 1). Glutopik cihazı ile hesaplanmış GSAB değerleri ise iki yıl ortalaması olarak sulu lokasyonda \%63.6 (v/w), kuru lokasyonda ise \%62.7 (v/w) olarak hesaplanmıştır. Genotipler arasında farklılıkların $\mathrm{P}<0.01$ düzeyinde önemli, yıllar arasındaki farklılıkların ise sulu lokasyonda $P<0.05$, kuru lokasyonda $\mathrm{P}<0.01$ seviyesinde önemli olduğu belirlenmiştir (Çizelge 2). GSAB ile PRT arasında $r=$ $0.3726 \mathrm{P}<0.01$, SRT ile $r=0.4828 \mathrm{P}<0.01$, $\mathrm{YGLT}$ ile $r=0.4322 P<0.01$, FSAB ile $r=0.8280 P<0.01$, AW arasında ise $r=0.3684 P<0.01$ pozitif ve önemli korelasyon olduğu bulunmuştur (Çizelge 3). GSAB ile FSAB arasındaki regresyon ilişkisi ise Şekil $1 d$ 'de görüldüğü gibidir. Regresyon eşitliği $P<0.01$ düzeyinde önemli bulunmuştur. Regresyon daha doğrusal bir ilişki göstermiştir. GSAB çalışması, FSAB hakkında yakın bilgi vermektedir. Genotiplerin FSAB değeri bakımından sulu ve kuru lokasyonda sırasıyla \%66.4 (v/w) ve \%66.7 (v/w) ile Bayındır ilk sırada, \%55.7 (v/w) ve \%54.9 (v/w) ile Şehzade son sırada yer almıştır. Diğer genotiplerin değerleri bu değerler arasında dağılım göstermiştir (Çizelge 1). GSAB değerine göre ise sulu ve kuru lokasyonda sırasıyla \%72.3 (v/w) ve \%71.5 (v/w) ile Bayındır ilk sırada yer almıştır. Sulu lokasyonda \%59.8 (v/w) ile Şehzade, kuru lokasyonda \%58.6 (v/w) ile Meke son sırada yer almışlardır (Çizelge 2). Güçbilmez ve ark. (2019), GSAB ile FSAB arasında $r=0.9158 ; P<0.01$ düzeyinde önemli ilişki bulunduğunu belirtmişlerdir. Şahin ve ark. (2013) yapılan bir çalışmada FSAB değerinin \%52.6 ve 70.8 (v/w) arasında değiştiğini, ortalama değeri \%63.1 (v/w) olarak bulduklarını belirtmişlerdir. Bu sonuçlar çalışmadaki bulgularla paralellik göstermektedir.

Start up enerji (S. enerji) ve agregasyon enerji (Ag. enerji)

Glutopik diyagramında start up enerji ve agregasyon enerji değeri hesaplanmaktadır. Start up enerji değeri ile genotipler arasındaki farklılıklar $\quad P<0.01$ seviyesinde önemli bulunmasına rağmen hem kuru hem de sulu 
lokasyonda yıllar arasındaki farklılıklar önemsiz bulunmuştur (Çizelge 2). Start up enerji değeri ile PRT arasında $r=0.2619 P<0.01$, SRT ile $r=0.2416$ $P<0.05$, YGLT ile $r=0.2198 P<0.05, F S A B$ ile $r=$ $0.4441 P<0.01$, pozitif ve önemli korelasyon olduğu, AW arasında ise $r=0.1636$ önemsiz korelasyon olduğu belirlenmiştir (Çizelge 3 ). S. enerji ile PRT ve FSAB arasındaki korelasyonun yüksek ve istatistiki olarak önemli olduğu görülürken SRT, YGLT, AW arasında nispeten daha düşük olduğu belirlenmiştir. Agregasyon enerji değeri sulu lokasyon ortalaması 1594.5, kuru lokasyon ortalaması ise 1471.2 olarak belirlenmiştir. Genotipler ve yıllar arasındaki farklılıklar istatistiki olarak $\mathrm{P}<0.01$ seviyesinde önemli bulunmuştur (Çizelge 2). Ag.enerji değeri ile PRT arasında $r=0.2828 P<0.01$, SRT ile $r=$ $0.2520 P<0.01$, YGLT ile $r=0.3429 P<0.01$, FSAB ile $r=0.6825 \mathrm{P}<0.01$, AW arasında ise $r=0.4049$ $\mathrm{P}<0.01$ seviyesinde pozitif ve önemli korelasyon olduğu bulunmuştur. Ag. enerji değeri ile buğday unu reolojik özellikleri arasındaki ilişki, S. enerji değerine göre daha yüksek bulunmuştur. Gluten kalitesinin belirlenmesinde $\mathrm{Ag}$. enerji değerinin kullanılmasının daha uygun olacağı düşüncesi oluşmuştur.

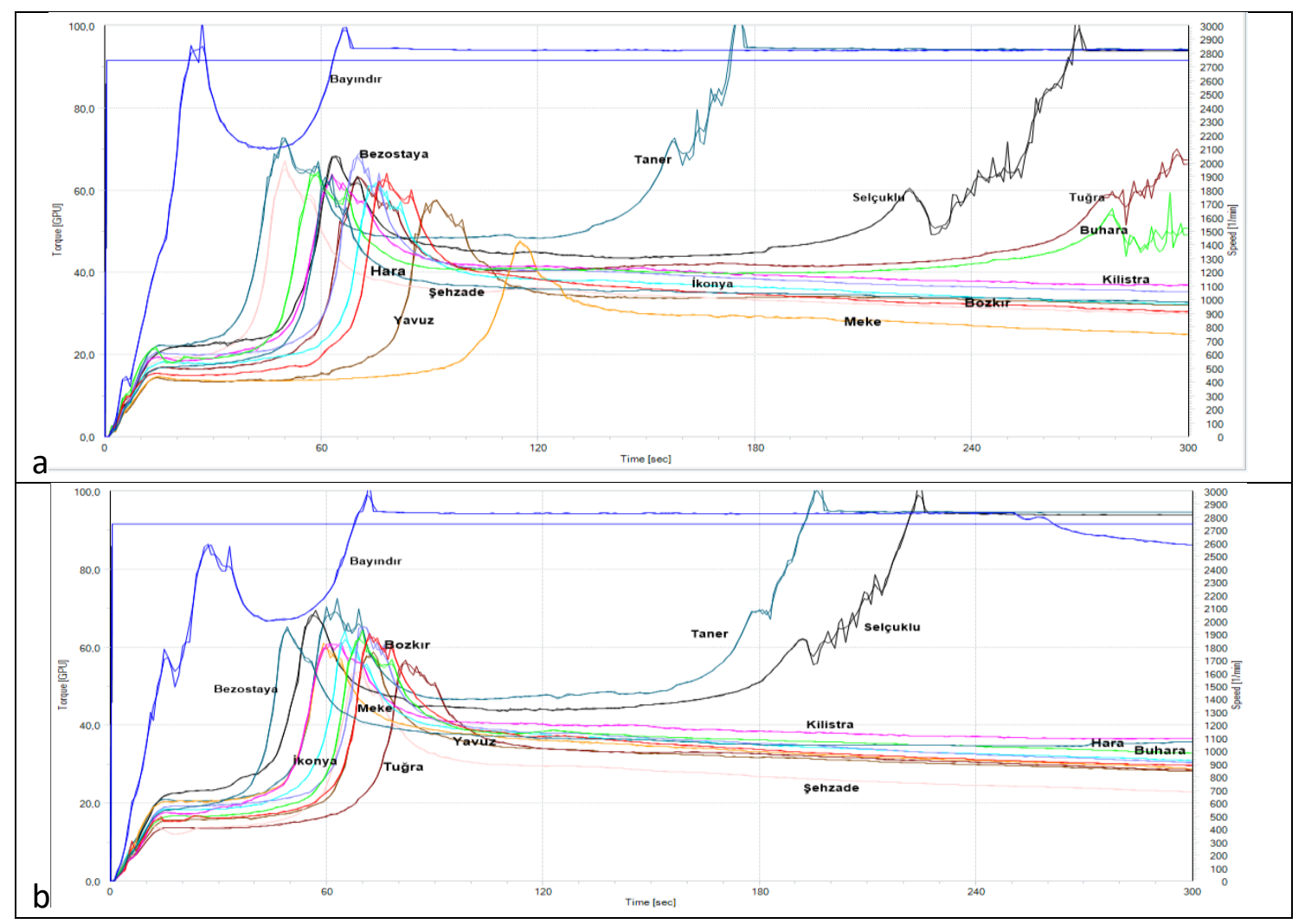

Şekil 2. 2017-2018 yılı a) kuru, b) sulu lokasyon genotiplerin Glutopik diyagramları

Figure 2. GlutoPeak diagrams of a) rainfed, b) irrigated location genotypes grown in 2017-2018 season

\section{Glutopik diyagramları}

iki yıl iki lokasyonda yetiştirilen genotiplerin glutopik diyagramları Şekil 2 ve 3 'de görülmektedir. Diyagramlar incelendiği zaman her genotipin kendine has bir diyagram şekline sahip olduğu görülmektedir. Bayındır genotipinin diğer genotiplerden farklı olarak gluteninin kısa sürede toparlanarak maksimum tork değerine ulaştığı yumuşama sürecinden sonra tekrar yukarı doğru pik vererek diyagramın üst kısmından devam ettiği, en düşük PMT değerine sahip olurken çevre şartlarından çok fazla etkilenmediğini söyleyebiliriz. 2017-2018 kuru diyagramında Taner, Selçuklu, Tuğra, Buhara genotipleri kuru lokasyonda maksimum torktan sonra yumuşamaya başlayan glutenin tekrar toparlanarak piklerin diyagramın üst kısmından ilerlediği, Taner ve Selçuklu genotiplerinin sulu lokasyonda da benzer diyagram verdiği görülmektedir.2018-2019 yılında kuru lokasyonda Bayındır ile birlikte Selçuklu genotipi yumuşamadan sonra tekrar toparlanmış olup, 
sulu lokasyon diyagramında ise Buhara, Taner, Selçuklu, Kilistra, Bozkır, Yavuz genotiplerinin yumuşama sürecinden sonra tekrar toparlanma sürecine girdiği görülmüştür (Şekil 3).

Diğer genotiplerin ise maksimum torktan sonra yumuşamaya başladığı ve tekrar toparlanma olmadığı görülmektedir. $\mathrm{Bu}$ da glutopik diyagramına genotiplerin genetiksel özelliğinin yanında çevrenin de (o yılın yağış, sıcaklık v.b) durumları glutopik diyagramlarını etkilediklerini söyleyebiliriz. 2017-2018 yetiştirme yılı kuru lokasyonda Yavuz ve Tuğra genotiplerinin, sulu lokasyonda ise Tuğra ve Şehzade'nin en yüksek PMT değerine sahip olduğu belirlenmiştir. 20182019 yılı sulu lokasyonda Şehzade ve Meke genotipleri, kuru lokasyonda ise Şehzade ve Tuğra genotiplerinin en yüksek PMT değerine sahip olduğu belirlenmiştir. Buna göre gluten toplanma süresinin diğer genotiplere göre daha uzun sürede oldukları için gluten kalitelerinin diğer genotiplere göre daha düşük oldukları söylenebilir. Glutopik diyagramı üst kısma yakın ise tork değerleri yüksek ve gluten kalitesi iyi, alt kısma yakın ve yatay oluşanlar ise tork değerleri düşük ve yumuşak olarak değerlendirilmekte gluten kalitesinin zayıflığına işaret etmektedir.

\section{Özelliklerin PCA analizi}

Glutopik verileri ve unun reolojik özellikleri PCA analizi yapıldığı zaman PRT, YGLT, AW vektörleri aynı yönde ve birbirine yakın şekilde oluşmuştur. Bu özellikler arasındaki ilişkinin yüksek olduğunu göstermektedir. SRT vektörü sağ alt bölgede yer almış ama diğer özellik vektörleri ile aynı yönde ve PMT hariç diğer özelliklerle aralarındaki açı dar açıdır. Bu durumda diğer özelliklerle doğrusal ve pozitif ilişki göstermektedir. Glutopik özellikleri AM, PM, BEM, PMT, GPRT, GGLT, GW, GSAB, S.enerji, Ag. enerji aynı yönde ve birbirlerine yakın vektörler olduğundan aralarındaki ilişkinin yüksek olduğu görülmektedir. PMT ile diğer özellikler arasında negatif ilişki olduğu PCA analiz şeklinden görülmektedir (Şekil 4). Şahin ve ark., (2011) çeşitlerin stabilitelerini inceledikleri çalışmada protein oranı ve yaş gluten vektörlerinin aynı yönde ve birbirine yakın yer aldıklarını belirtmişlerdir.

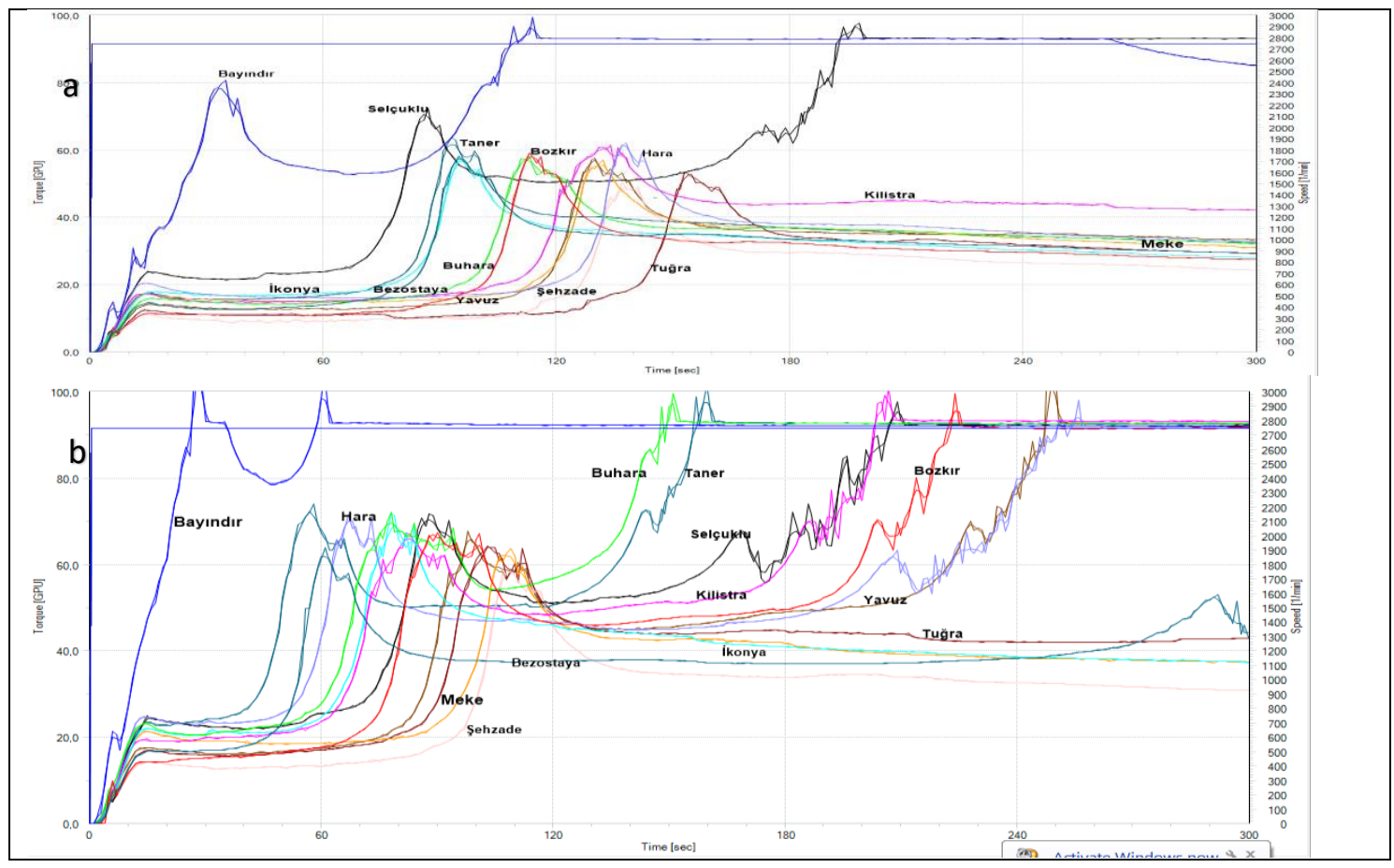

Şekil 3. 2018-2019 yılı a)kuru, b) sulu lokasyon genotiplerin Glutopik diyagramları

Figure 3. GlutoPeak diagrams of a) rainfed, b) irrigated location genotypes grown in 2018-2019 season. 


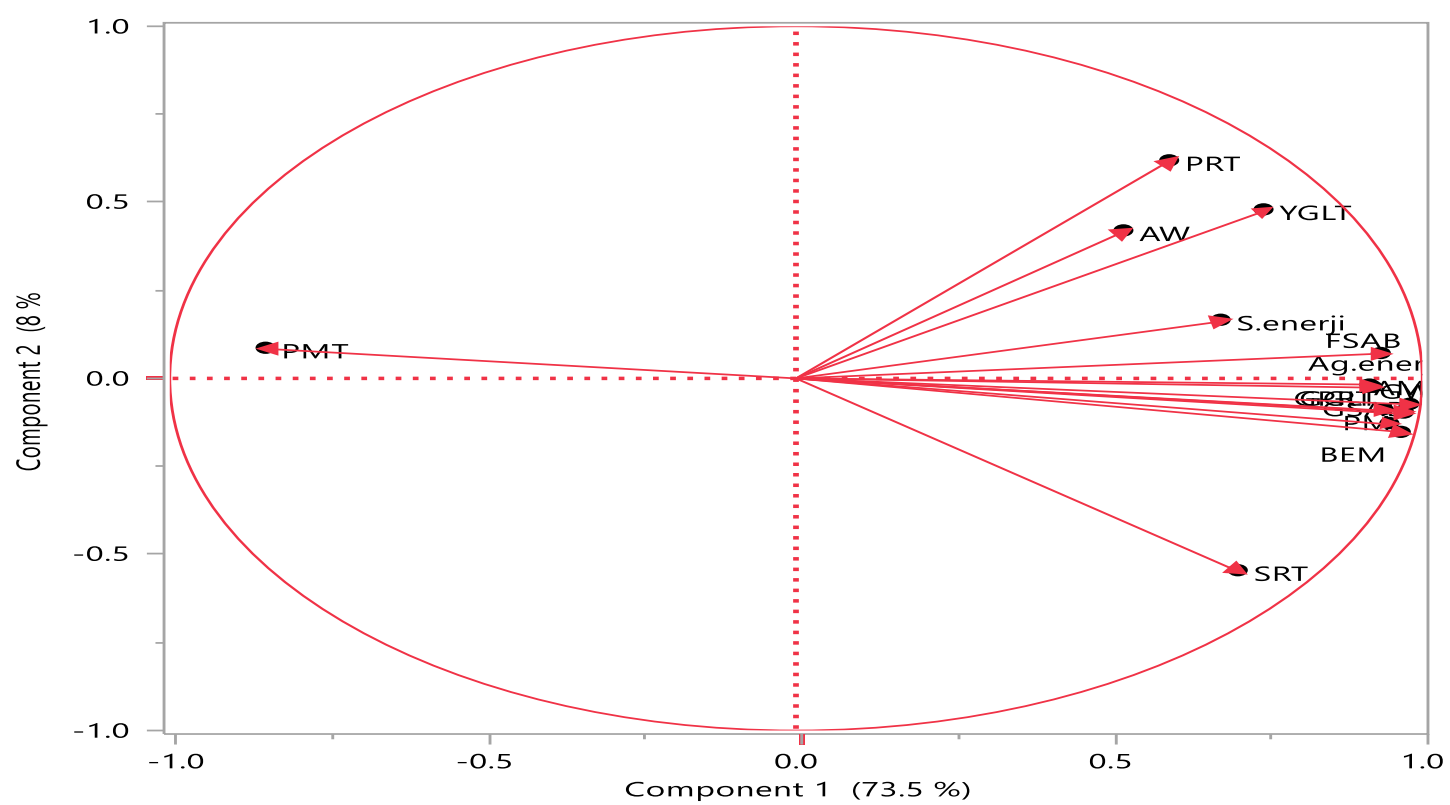

Şekil 4. Buğday unu reolojik özellikler ve Glutopik diyagramı verileri komponent analizi

Figure 4. Component analysis of wheat flour rheological properties and GlutoPeak diagram data

Çizelge 4. Glutopik cihazında yapılan analizlerle klasik yöntemle yapılan analizlerin eşli t testi yöntemi ile önemlilik kontrolü Table 4. Paired t test Significance control of the analyzes made with the classical method with the analysis made on the glutopic device with the method of matched pairs

\begin{tabular}{lccccc}
\hline $\begin{array}{l}\text { Özellik } \\
\text { Trait }\end{array}$ & $\begin{array}{c}\text { Ortalama } \\
\text { Mean }\end{array}$ & $\begin{array}{c}\text { Ortalama fark } \\
\text { Mean difference }\end{array}$ & $\begin{array}{c}\text { t değeri } \\
\text { t-value }\end{array}$ & $\begin{array}{c}\text { Olasılık } \\
\text { Probablity }\end{array}$ & $\begin{array}{c}\text { Önemlilik değeri } \\
\text { Significant degree }\end{array}$ \\
\hline GPRT-PRT & $12.53-13.22$ & -0.6903 & -6.091 & Prob $>|t|$ & $<0.001$ \\
GGLTN-YGLT & $29,28-34,91$ & -5.6434 & -12.54 & Prob $>|t|$ & $<0.001$ \\
GSAB-FSAB & $63.15-59.97$ & 3.175 & 16.92 & Prob $>|t|$ & $<0.001$ \\
GW-AW & $376.8-196.4$ & 180.4 & 20.55 & Prob $>|\mathrm{t}|$ & $<0.001$ \\
\hline
\end{tabular}

Glutopik cihazından elde edilen veriler GPRT, GGLTN, GSAB, GW verileri klasik metotlarla elde edilen PRT, YGLT, FSAB, AW özellikleri eş yapma yöntemi ile aralarındaki fark önemlilik kontrolü yapılmıştır. İki yıl kuru ve sulu lokasyonlarda yetiştirilen 13 buğday çeşidinde yapılan özellikler arasındaki farklar önemli bulunmuştur (Çizelge.4). Glutopik cihazının vermiş olduğu GPRT, GGLTN, GSAB ile klasik usulde yapılan analizler arasında istatistiki olarak önemli fark olsa bile birbirine yakın sonuç vermektedir. Ancak GW ile AW arasında yüksek fark belirlenmiştir. Buna rağmen glutopik diyagramı görsel olarak incelendiği zaman iyi gluten kalitesine sahip çeşitler ayırt edilebilmektedir.

\section{Sonuç}

Ekmeklik buğdaylarda gluten kalitesini değerlendirmek için geliştirilmiş olan Glutopik cihazı ile Hızı Un Kontrol metoduna göre yapılan analiz sonucu elde edilen verilere göre $A M, B E M$ $P M$ ve $\mathrm{Ag}$. enerji değerlerinin yüksekliği gluten kalitesinin yüksek olmasına işaret ederken PMT değerinin yüksekliği ise glutenin geç toparlanmasına ve kalitesinin düşük olmasına işaret etmektedir. Hızlı Un Kontrol metoduna göre GSAB değeri ile $F S A B$ arasında yüksek bir korelasyon $(r=0.8280, P<0.01)$ olduğu ve doğrusal bir regresyon gösterdiği belirlenmiştir.

GPRT ile PRT arasında $r=0.3592, P<0.01$ düzeyinde, GGLT ile YGLT arasında $r=0.3506$, $\mathrm{P}<0.01$ düzeyinde, $\mathrm{GW}$ ile $\mathrm{AW}$ arasında $(r=0.3919$, $\mathrm{P}<0.01)$ ilişki olduğu belirlenmiştir. Ancak, bazı genotiplerin $\mathrm{AW}$ değeri düşük olmasına rağmen GW değerinin yüksek hesaplanması söz konusu olmaktadır. Bu çalışmada, İkonya genotipinin AW değeri sulu lokasyonda $150.5 * 10^{-4} \mathrm{~J}, \mathrm{GW}$ değeri $385.8 * 10^{-4} \mathrm{~J}$, kuru lokasyonda $162.2 * 10^{-4} \mathrm{~J}, \mathrm{GW}$ değeri $332.0 * 10^{-4} \mathrm{~J}$ olarak belirlenmiştir. Buğday protein oranı, yaş gluten oranı, su absorbsiyonu açısından ıslah çalışmalarında az örnekle kısa 
sürede sonuç vermesinden dolayı faydalı olacağı düşüncesi oluşmuştur.

\section{Çıkar Çatışması Beyanı: Makale yazarları} aralarında herhangi bir çıkar çatışması olmadığını beyan eder.

\section{Kaynaklar}

Anonymous (2000a). Official Methods of Analysis of Association of Official Analytical Chemists(AOAC), 17th ed. Method 992.23. Gaithersburg, MD.

Anonymous (2000b). Approved Methods of American Association of Cereal Chemists (AACC), 10th ed. Methods. Minnesota, USA.

Banu, I., \& Aprodu, I. (2015). Association of physicochemical with technological properties of wheat. International Journal of Food Science \& Technology. 50: 1644-1650.

Bouchra, S., Begemann, J., Arab, L. \& Hüsken, A. (2017). Prediction of Bread wheat baking quality using an optimized Glotopeak-Test Method. Journal of Cereals Science 76: 8-16.

Chandi, G. K. \& Seetharaman K. (2012). Optimization of gluten peak tester: A statistical approach. Journal of Food Quality. 35: 69-75.

Giovenzana, V., Beghi, R., Malegori, C., Civelli, R. \& Guidetti, R. (2013). Wavelength selection with a view to a simplified handheld optical system to estimate grape ripeness. American Journal of Enology and Viticulture. 65: 117-123

Gupta, R. R., Batey, I. L. \& MacRitchie, F. (1992). Relationships between protein composition and functional properties of wheat flours. Cereal Chemistry. 69: 125-131.

Güçbilmez, Ç. M., Şahin, M., Akçacık, A. G., Aydoğan, S., Demir, B., Hamzaoğlu, S., Gür, S. \& Yakışır, E. (2019). Evaluation of GlutoPeak test for prediction of bread wheat flour quality, rheological properties and baking performance. Journal of Cereal Science. 90: 19.

Karaduman, Y., Akın, A., Türkölmez, S. \& Tunca, Z. Ş. (2015). Ekmeklik buğday ıslah programlarında gluten kalitesinin değerlendirilmesi için glutopik parametrelerinin kullanılabilirliğinin araştırılması. Tarla Bitkileri Merkez Araştırma Enstitüsü Dergisi. 24 (1): 65-74.

Karaduman, Y., Önder, O., Sayaslan, A. \&Aydın, N. (2019). Utilisation of Glutopeak Taster on Whole-wheat flour for gluten quality assesment. Quality Assurance and Safety of crops \& Foods. 11(3): 295-304.

Malegori, C., Grassi, S., Ohm, J., Anderson, J. \& Marti, A. (2018). GlutoPeak profile analysis for wheat classification: skipping the refinement process. Journal of Cereal Science 79: 73-79.

Marti, A., Ulrici, A., Foca, G., Quaglia, L. \&Pagani, M. A. (2015). Characterization of common wheat flours (Triticum aestivum L.) through multivariate analysisi of conventional rheological parameters and gluten peak test indices. LWT - Food Science and Technology. 64: 95-103.

Pastor, K., A, Canski, M., Vujic, D., Bekavac, G., Milovac, S. \& Kravic, S. (2016). Rapid method for small grain and corn flour authentication using gc/eiems and multivariate analysis. Food Analytical Methods. 9: 443-450.

Rakita, S., Dokić, L., Hadnad-ev, T. D., Hadnad-ev M. \& Torbica, A. (2018). Predicting rheological behavior and baking quality of wheat flour using a GlutoPeak test. Journal of Texture Studies. 49(3):339-347. doi: 10.1111/jtxs.12308.

Şahin, M., Göçmen Akçacık, A., Aydoğan, S., Demir, B., Önmez, H. \& Taner, S. (2013). Ekmeklik Buğday ununda ekmek hacmi ile bazı fizikokimyasal ve reolojik özellikler arasındaki ilişkilerin tespiti. Tarla Bitkileri Merkez Araştırma Enstitüsü Dergisi. 22 (1): 13-19.

Şahin, M., Göçmen Akçacık, A. \& Aydoğan, S. (2011). Bazı ekmeklik buğday genotiplerinin tane verimi ile kalite özellikleri arasındaki ilişkiler ve stabilite yetenekleri. Anadolu Ege Tarımsal Araştırma Enstitüsü Dergisi 21(2): 39-48.

Wang, J., Hou, G. G., Liu, T., Wang, N. \& Bock, J. (2018) GlutoPeak method improvement for gluten aggregation measurement of whole wheat flour. Food Science and Technology. 90: 8-14.

Wiertz, J. (2018). GlutoPeak methods- RFC. In: Wiertz, J. (Ed.), Brabender ${ }^{\circledR} \mathrm{GmbH}$ \& Co. KG-Sales Seminar 2018 GlutoPeak Methods- a Quick Overview, pp. 713 Germany 